\title{
Four pieces of advice for new neurologists
}

Michael Wynn, DO

Neurolog ${ }^{\circledR}$ 2020;95:698. doi:10.1212/WNL.0000000000010630
Correspondence

Dr. Wynn

mwynn@wynn.mvipa.org

1.

A demented patient remembers more

than she has forgotten. Remember this.

She will forget to remind you.

Focus on the picnic she had

with her love under the Chestnut tree-

iced tea, peanut butter pie, Verdi on the BBC,

then listen to her describe her scars

from her days in the Women's Army Corps.

2.

If a patient is older than 85 talk to him

like he is 105

or 30. Even better, don't talk.

3.

Mr. Smith is angry at his stiff leg

and right hand tremor. His language

is colorful as a medieval flag

carried into battle.

Imagine the gibbous moon

rising over Agincourt, the field

all black arrows and scarlet ego.

October mist rises and swirls

flowing with easy purpose

over the newly dead

without deference to lineage.

Mr. Smith wants to move like that.

4.

You are as full of promise

as a not-quite-ripe lime.

More than knowledge,

what you have to offer your first patient,

is ancient. A Bristlecone pine.

Be ageless. 


\section{Neurology}

\section{Four pieces of advice for new neurologists \\ Michael Wynn}

Neurology 2020;95;698 Published Online before print August 11, 2020

DOI 10.1212/WNL.0000000000010630

This information is current as of August 11, 2020

\section{Updated Information \&} Services

\section{Subspecialty Collections}

Permissions \& Licensing

Reprints including high resolution figures, can be found at: http://n.neurology.org/content/95/15/698.full

This article, along with others on similar topics, appears in the following collection(s):

\section{All Cognitive Disorders/Dementia}

http://n.neurology.org/cgi/collection/all_cognitive_disorders_dementia All Education

http://n.neurology.org/cgi/collection/all_education

Clinical neurology history

http://n.neurology.org/cgi/collection/clinical_neurology_history

Parkinson's disease/Parkinsonism

http://n.neurology.org/cgi/collection/parkinsons_disease_parkinsonism

Information about reproducing this article in parts (figures,tables) or in its entirety can be found online at:

http://www.neurology.org/about/about_the_journal\#permissions

Information about ordering reprints can be found online:

http://n.neurology.org/subscribers/advertise

Neurology ${ }^{\circledR}$ is the official journal of the American Academy of Neurology. Published continuously since 1951, it is now a weekly with 48 issues per year. Copyright @ 2020 American Academy of Neurology. All rights reserved. Print ISSN: 0028-3878. Online ISSN: 1526-632X.

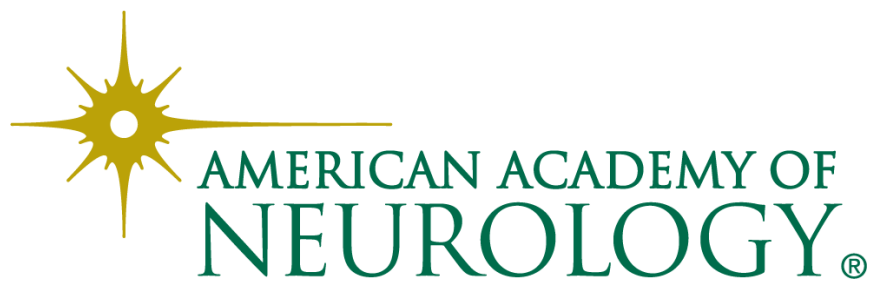

